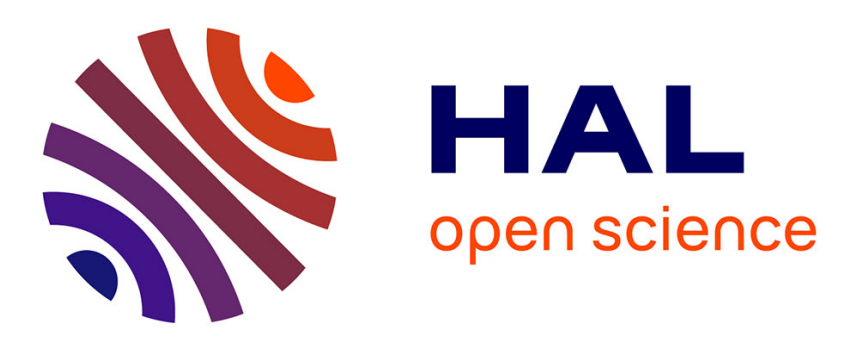

\title{
New developments in Yarrowia lipolytica yeast expression system and its application to genetic engineering of heterologous proteins
}

Catherine Madzak

\section{- To cite this version: \\ Catherine Madzak. New developments in Yarrowia lipolytica yeast expression system and its applica- tion to genetic engineering of heterologous proteins. 3. World Congress on Biotechnology, Sep 2012, Hyderabad, India. 10.4172/2155-952X.S1.020 . hal-02746951}

\section{HAL Id: hal-02746951 \\ https://hal.inrae.fr/hal-02746951}

Submitted on 3 Jun 2020

HAL is a multi-disciplinary open access archive for the deposit and dissemination of scientific research documents, whether they are published or not. The documents may come from teaching and research institutions in France or abroad, or from public or private research centers.
L'archive ouverte pluridisciplinaire HAL, est destinée au dépôt et à la diffusion de documents scientifiques de niveau recherche, publiés ou non, émanant des établissements d'enseignement et de recherche français ou étrangers, des laboratoires publics ou privés. 


\title{
$3^{\text {rd }}$ World Congress on \\ C o n f e r e n c e s \\ Accelerating Scientific Discovery

\section{New developments in Yarrowia lipolytica yeast expression system and its application to genetic engineering of heterologous proteins}

Catherine Madzak

French National Institute for Agricultural Research, France

$\mathrm{M}$ ore than 100 heterologous proteins from various phylogenetic origins have been successfully produced in Yarrowia lipolytica yeast expression system, which offers reliable performances in glycosylation, folding and secretion of complex proteins. We present here a short review of the major tools developed in this yeast, with focus on vectors for targeted monocopy integration (YLEX expression kit, Yeastern Biotech Co, Taiwan), a system particularly adapted to genetic engineering of heterologous proteins. In order to examplify the various applications of Yarrowia expression system, a number of current collaborative works on wholecell biocatalysis, genetic engineering of secreted enzymes, and surface-display of heterologous proteins (arming yeasts) will be briefly resumed. Some applications, like high throughput screening, require improving Yarrowia transformation methods for higher efficiency, without sacrificing the high percentage of correctly targeted integrations. For that purpose, we have developed a sensor system for homologous integration, based on E. coli lacZ gene expression, which allowed us to evaluate some chemicals increasing transformation efficiency for maintenance of a high percentage of correct integration. Dithiothreitol was found to be not only more efficient than dimethyl-sulfoxide in increasing transformation efficiency, but also compatible with homologous integration, which was not the case of the latter that promoted out-of-site integration. An optimized transformation protocol using dithiothreitol has been developed, which ensures very high transformation efficiency.

\section{Biography}

Catherine Madzak has been a student at Ecole Normale Supérieure, one of the main French governmental schools of higher education. She obtained her Ph.D. in Microbiology at the Cancer Institute of Villejuif. She is now a senior research associate at INRA, the French National Institute for Agricultural Research. Her main research subject is to develop an expression system for heterologous proteins in the yeast Yarrowia lipolytica, with particular emphasis on genetic engineering of enzymes. She is author of more than 40 publications in international journals, five book chapters, and inventor of a patent on a recombinant promoter.

\section{Enzymatic modification of chitosan using chitin deacetylase isolated from Bacillus cereus}

\section{Ritu Raval', Keyur Raval' and B. Moerschbacher ${ }^{2}$}

'Manipal Institute of Technology, India

${ }^{2}$ Institut für Biochemie und Biotechnologie der Pflanzen, Germany

\begin{abstract}
The advent of molecular technologies, protein engineering and directed evolution, new avenues are being opened to make use 1 of the enormous diversity of natural biopolymers. Polysaccharides are at the forefront of this rediscovery of natural resources, not only for the shear quantity of their production but also for the amazing quality and diversity of their physico-chemical properties and biological functionalities.

One of the classes of polysaccharide with a promising economic potential comprises those with biological activities, such as chitosan, heparin, hyaluronic acids, and other glycosaminoglycans. All of these diverse polysaccharides have been optimised over the course of evolution to fulfil their many roles in the life of bacteria, fungi, plants, animals, and humans. However, there is still considerable leeway for optimisation of these biopolymers to fulfil their many roles in biotechnology. Today, modifications and optimisations are typically done using chemical methods such as acid or alkali treatment. Alternative and/or complementing enzymatic modifications will reduce energy input and environmental impact while at the same time offering the advantage of higher specificity and, thus, potentially yielding novel polymers and/or oligomers with advanced physico-chemical properties and biological functionalities. In the following research work, one of the isolated chitin deacetylase (CDA) from Bacillus cereus was cloned in E.coli pLys strain and the activity was checked for on chitohexamers.
\end{abstract}

\section{Biography}

Ritu Raval was awarded her PhD degree from IIT Delhi under the mentorship of Prof. Prashant Mishra. She later moved to Germany for her postdoctoral experience in recombinant technology which involved both red and green biotechnology. She currently is employed with Manipal University, India wherein her main focus of interest is Expression of recombinant genes and their further scale up. She has authored four publications and one book chapter.

ritu.raval@manipal.edu 